a Universidade Federal de São João del Rei, Departamento de Ciências Naturais, Campus Dom Bosco, Praça Dom Helvécio 74, Fábricas, CEP 36301-160, São João del Rei-MG, Brasil.

*E-mail: arnaldocsp@ yahoo.com.br

Recebido em: 29 de Outubro de 2020

Aceito em: 21 de Junho de 2021

Publicado online: 25 de Outubro de 2021

\section{Electrochemical Sensor Based on Carbon Paste Modified by Cobalt(II) Porphyrin for Ascorbic Acid Determination}

\author{
Sensor Eletroquímico à Base de Pasta de Carbono Modificada com \\ Porfirina de Cobalto(II) para a Determinação de Ácido Ascórbico
}

Samuel de Almeida Caldeira, ${ }^{a}$ Daniela Nunes da Silva, ${ }^{a}$ Arnaldo César Pereira ${ }^{a, *}$ (1)

\begin{abstract}
Ascorbic acid (AA) is widely used in the food, cosmetics and pharmaceutical industries. Therefore, the development of sensitive, fast and cost-effective analytical method for AA determination is very relevant in these areas. In this work, an electrochemical sensor was developed based on carbon paste modified by cobalt(II) porphyrin complex immobilized on silica $\left(\mathrm{SiO}_{2} / \mathrm{TiO}_{2}\right)$ obtained by the sol-gel processing method, for AA detection. The modifying material, SiTiPPCo, was characterized by Scanning Electron Microscopy (SEM) and Fourier Transform Infrared Spectroscopy (FT-IR). The modified electrode (CPE-SiTiPPCo) results have shown excellent performance in the determination of AA. The method proposed presented linear range from $7.0 \mu \mathrm{mol} \mathrm{L} \mathrm{L}^{-1}$ to $70.0 \mu \mathrm{mol} \mathrm{L} \mathrm{L}^{-1}(\mathrm{r}=0.9986)$, with detection and quantification limits of $1.9 \mu \mathrm{mol} \mathrm{L} \mathrm{L}^{-1}$ and $6.4 \mu \mathrm{mol} \mathrm{L} \mathrm{L}^{-1}$, respectively. CPE-SiTiPPCo was successfully applied to determine AA in samples of pharmaceutical formulation $\left(\right.$ Energil $\mathrm{C}^{\circledR}$ ) with a relative standard deviation (RSD) lower than $4.08 \%$.
\end{abstract}

Keywords: Electrochemical sensor; ascorbic acid; carbon paste electrode, cobalt(II) porphyrin complex

\section{Introduction}

Ascorbic acid (AA), also known as vitamin $\mathrm{C}$, is a hydrosoluble vitamin that exists as two enantiomers. The $\mathrm{L}$ isomer is the one most often found. ${ }^{1}$

AA play an essential role in human metabolisms such as enzyme cofactor, chemical reductant and antioxidant. ${ }^{2} \mathrm{AA}$ is widely used in the food, cosmetics and pharmaceutical industries due of its antioxidant properties. ${ }^{3}$

The deficiency of AA is associated with causes various diseases such as scurvy, deterioration of collagen, cardiovascular disease, common cold, mental illness, infertility and lowering of body resistance from infections. By contrast, excessive amounts of AA are harmful for health and may cause gastric irritation and renal disorders. ${ }^{4}$ Thus, the development of a sensitive, fast and cost-effective analytical method for the determination of AA is important for healthcare and quality control of pharmaceuticals.

Several analytical methods have been described in the literature for AA determination such as Colorimetry, ${ }^{5}$ Spectrophotometry, ${ }^{6,7}$ Chromatography, ${ }^{8,9}$ Capillary Electrophoresis ${ }^{10}$ and Fluorescence Techniques. ${ }^{11}$ The electrochemical determination of AA it has also been reported since AA is an electroactive compound. ${ }^{1,12-14}$

Sensors based on Electrochemical Techniques are widely used due their advantages such as easy preparation, high sensitivity and low cost. ${ }^{15}$ Another advantage is that the sensitivity and selectivity of the electroanalytical response can be improved with the use of chemically modified electrodes. ${ }^{16}$

Metalloporphyrins adsorbed on porous solid substrates, such as silica, have been used as modifying materials in the development of sensors. ${ }^{17}$ Porphyrin derivatives are use as electron mediators due to electrocatalytic activity. ${ }^{18}$

Wang et al. described a DNA sensor based on nanocomposite of reduced graphene oxide (RGO) and a modified manganese (III) tetraphenylporphyrin (MnTPP). Porphyrin were used because they have a versatility that allows functionalization with reactive groups and due to the ability to incorporate many redox metals. The proposed method presented a detection limit of $6 \times 10^{-14} \mathrm{~mol} \mathrm{~L}^{-1}{ }^{19}$

Therefore, the main objective of this study was to develop an electrochemical sensor based on carbon paste modified by cobalt(II) porphyrin complex immobilized on $\mathrm{SiO}_{2} / \mathrm{TiO}_{2}$ 
obtained by the sol-gel processing method for ascorbic acid determination in pharmaceutical formulation samples.

\section{Experimental}

\subsection{Reagents and materials}

L-ascorbic acid and graphite powder were purchased from Synth ${ }^{\circledR}$ (Diadema, SP, Brazil). Anhydrous monobasic sodium phosphate and dibasic sodium phosphate were obtained from Vetec ${ }^{\circledR}$ (Rio de Janeiro, RJ, Brazil). Mineral oil, piperazine-1,4-bis[2-ethanesulfonic acid] (PIPES), Tris[hydroxymethyl]aminomethane (Trizma), 4-[2-hydroxyethyl] piperazine-1-ethanesulfonic acid (HEPES) and sodium hydroxide were acquired from Sigma-Aldrich ${ }^{\circledast}$ (St. Louis, MO, USA). Cobalt(II) chloride hexahydrate was obtained from Dinâmica ${ }^{\circledR}$ (Diadema, SP, Brazil). All solutions were prepared with distilled and deionized water (resistivity: $>18 \mathrm{M} \Omega . \mathrm{cm}^{1}, 25^{\circ} \mathrm{C}$; Millipore ${ }^{\circledast}$ Milli-Q ${ }^{\circledast}$ purification system, Bedford, MA, USA).

The modified silica $\left(\mathrm{SiO}_{2} / \mathrm{TiO}_{2}\right)$ were synthesized by sol-gel process, after that the protoporphyrin- $\mathrm{IX}\left(\mathrm{H}_{2} \mathrm{PP}\right)$ was immobilized on silica surface (denominated SiTiPP), according to reported procedure in the literature..$^{20}$

Finally, the protoporphyrin metalation process was carried out. $0.3 \mathrm{~g}$ of SiTiPP were dispersed in $7.5 \mathrm{~mL}$ of an ethanoic solution of $\mathrm{CoCl}_{2} \cdot 6 \mathrm{H}_{2} \mathrm{O}\left(0.2 \mathrm{~mol} \mathrm{~L}^{-1}\right)$ and this system was constantly stirred for 19 hours followed by filtration and centrifuged. The material obtained was washed with water and ethanol and dried at $60^{\circ} \mathrm{C}$ for 1 hour. The material was denominated as SiTiPPCo.

\subsection{Preparation of CPE-SiTiPPCo}

The carbon paste electrode was prepared by mixing $15.00 \mathrm{mg}$ graphite powder, $15.00 \mathrm{mg}$ SiTiPPCo and $8.00 \mu \mathrm{L}$ mineral oil. The materials were mixed until complete homogenization, and the paste formed was introduced into the bottom cavity of a glass tube. This cavity has a platinum plate, which is connected to a nickel/chromium wire responsible for electrical contact of electrode.

\subsection{Apparatus}

The electrochemical analysis was obtained in a potentiostat/galvanostat (PGSTAT 204). Three electrodes were used, CPE-SiTiPPCo as working electrode; an $\mathrm{Ag} / \mathrm{AgCl} / \mathrm{KCl}\left(3.0 \mathrm{~mol} \mathrm{~L}^{-1}\right)$ electrode as reference electrode and a platinum wire as counter electrode. The materials were characterized by SEM and FT-IR. SEM images were obtained from a microscopy JEOL model JSM 300. The FT-IR spectra were recorded on Spectrum GX Perkin Elmer, by the $\mathrm{KBr}$ pellet technique.

\subsection{Method validation}

The validation of the developed analytical method was performed according to ANVISA standards. ${ }^{21}$ Therefore, linearity, detection limit (LOD), quantification limit (LOQ), precision (repeatability and intermediate precision) and accuracy were evaluated. Analyzes were performed in triplicate by Square Wave Voltammetry (SWV) technique.

\subsection{Preparation of pharmaceutical formulation}

AA tablets (Energil $\mathrm{C}^{\circledR} 1.00 \mathrm{~g}$ ) were purchased commercially. The samples were prepared from the maceration of these tablets. Then, solutions containing nominal concentrations of $15.00 \mu \mathrm{mol} \mathrm{L}^{-1}$ and $45.00 \mu \mathrm{mol} \mathrm{L}^{-1}$ of AA were analyzed.

\section{Results and Discussion}

\subsection{Characterization of materials}

Figure 1 shows SEM images of the SiTiPP and SiTiPPCo with magnification 1000 times. It was possible to observe that the materials are aggregated, it may be due to the formation of hydrogen interaction between the silane groups. ${ }^{22}$ The insertion of the metal in the immobilized protporphyrin in the silica matrix does not alter the material morphology (Figure 1b).

Figures 2 shows the infrared absorption spectrums of the silica samples. With the insertion of cobalt in the material, no new bands were observed. A broad band close to 3254 $\mathrm{cm}^{-1}$ is observed in both spectra, characteristic of the $\mathrm{OH}$ bond vibrations, which may be due to the presence of silanol groups $(\mathrm{Si}-\mathrm{OH})$ and the presence of water in the sample. For both samples, an intense band close to $1049 \mathrm{~cm}^{-1}$ was observed, attributed to the $\mathrm{Si}-\mathrm{O}-\mathrm{Si}$ group. Table 1 presents the observed bands. ${ }^{23}$

\subsection{Study of working electrode configuration}

Different electrode configurations were studied in the determination of AA. Figure 3 shows the cyclic voltammograms of the CPE, CPE-SiTiPP and CPE-SiTiPPCo. It was observed an irreversible oxidation peak for AA that was oxidated to dehydroascorbic acid. ${ }^{1}$ The modified electrode (CPE-SiTiPPCo) showed an anodic peak current increase of $77.41 \%$ and a $0.17 \mathrm{~V}$ reduction in oxidation potential when compared to the bare electrode. These results may be associated with electrocatalytic activity of the SiTiPPCo. Probably occurs a metalloporphyrin interaction with AA. The modified electrode without the metal (Figure 3b) presents low intensity of oxidation current, thus showing the importance of the presence of the metal. Dinatale et al. argue that the metal is important to determine the properties such as sensitivity and selectivity of the 

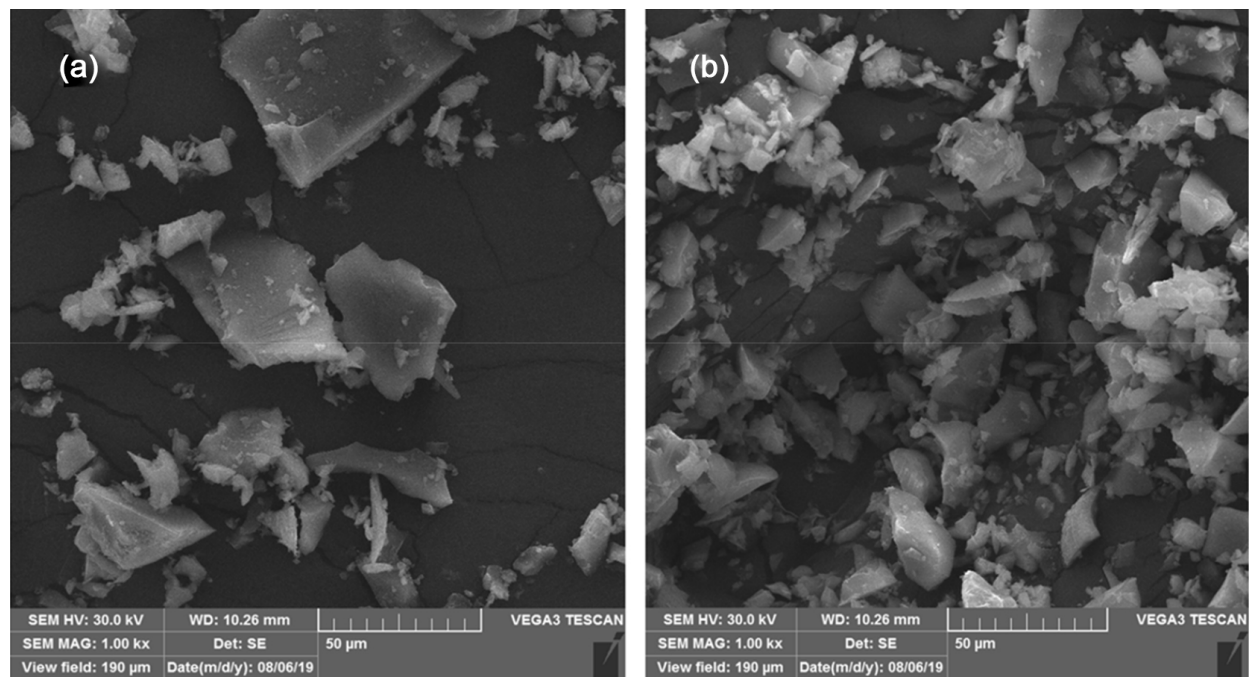

Figure 1. SEM images of (a) SiTiPP, (b) SiTiPPCo with magnification 1000 times
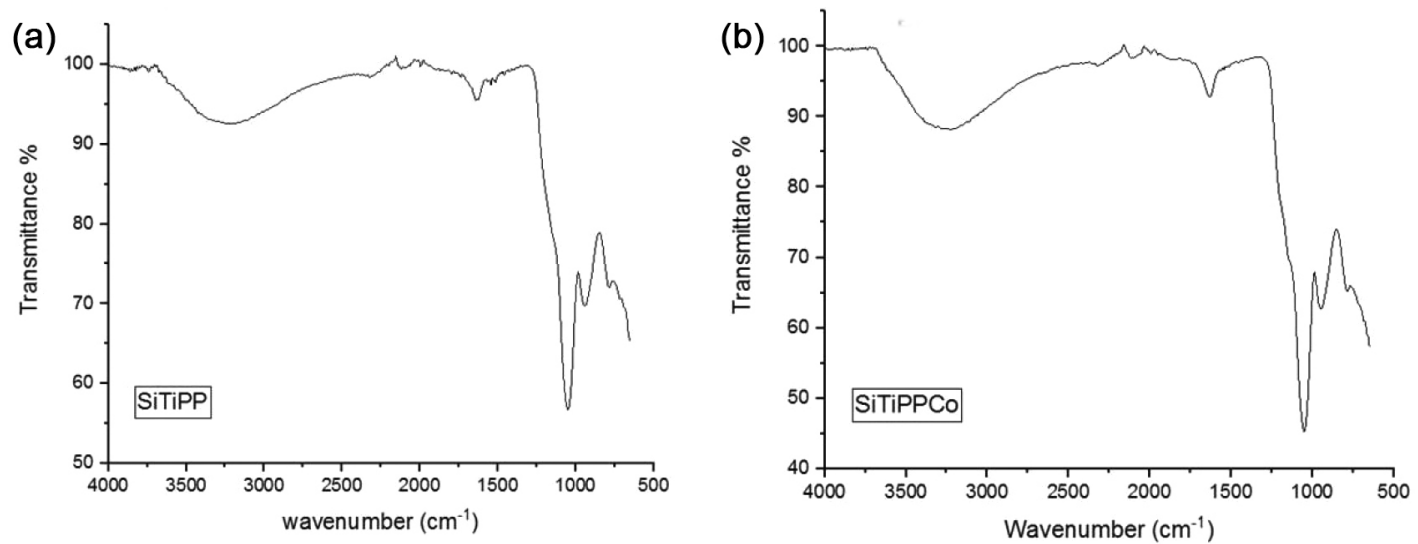

Figure 2. FT-IR spectrums of (a) SiTiPP; (b) SiTiPPCo

Table 1. Assignment of the bands observed in the SiTiPP and SiTiPPCo spectrums

\begin{tabular}{ccc}
\hline SiTiPP $\left(\mathbf{c m}^{-1}\right)$ & SiTiPPCo $\left(\mathbf{c m}^{-1}\right)$ & Assignment \\
\hline 3253 & 3254 & OH \\
1641 & 1629 & $(\mathrm{C}=\mathrm{C}) \mathrm{sp}^{2}$ \\
1045 & 1049 & Si-O-Si \\
930 & 920 & Si-OH \\
780 & 778 & Si-C \\
\hline
\end{tabular}

molecule this because coordination interactions occur at the metallic center in metalloporphyrin complexes. ${ }^{24}$

Scan rate also influences the redox process of electrode surface. A higher scan rate usually shift the peak potential to more positive regions. Thus, the scan rate of $20 \mathrm{mV} \mathrm{s}^{-1}$ was chosen.

\subsection{Influence of SiTiPPCo amount}

Figure 4 presents the result of the effect of SiTiPPCo amount on the proposed sensor. The amount of $15.00 \mathrm{mg}$ of silica was chosen as optimum due to the increase of AA oxidation current. There was a decrease in the analytical

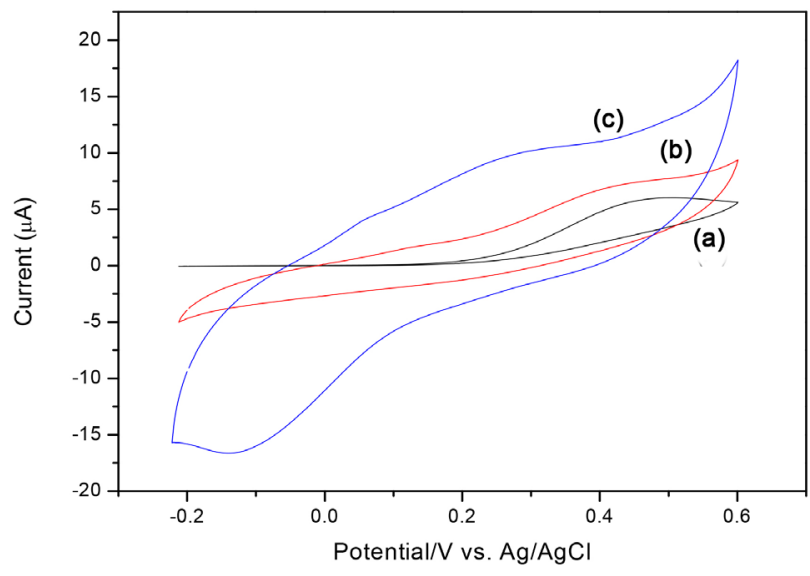

Figure 3. Cyclic voltammograms of $30 \mu \mathrm{mol} \mathrm{L} \mathrm{L}^{-1} \mathrm{AA}$ in $0.1 \mathrm{~mol} \mathrm{~L}^{-1}$ phosphate buffer (PBS) at pH 7.0 (a) CPE, (b) CPE-SiTiPP and

(c) CPE-SiTiPPCo, Scan rate: $20 \mathrm{mV} \mathrm{s}^{-1}$

signal with a larger amount of the modifier, this decrease is associated with a higher electrode resistivity.

\subsection{Influence of $\mathrm{pH}$}

The performance of the proposed electrode was 


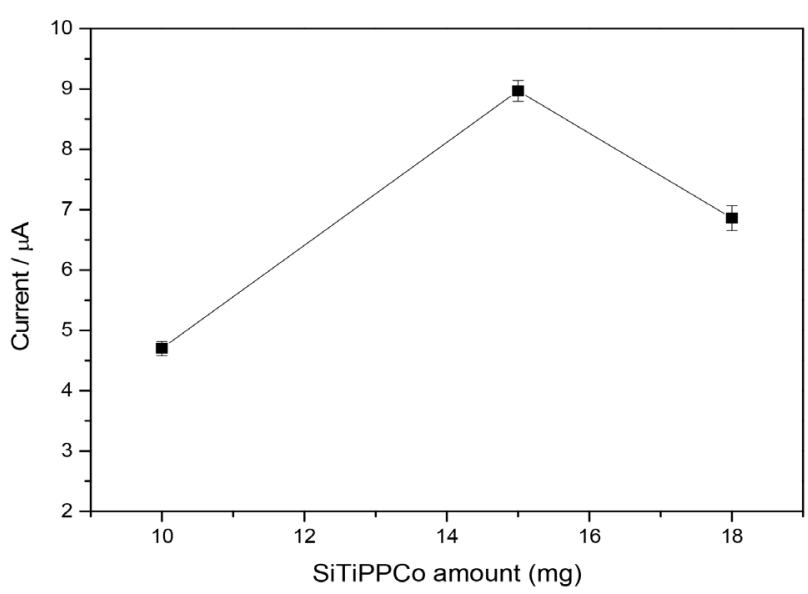

Figure 4. Influence of SiTiPPCo amount (mg) on anodic peak current at $30 \mu \mathrm{mol} \mathrm{L} \mathrm{L}^{-1} \mathrm{AA}$ in $0.1 \mathrm{~mol} \mathrm{~L}^{-1} \mathrm{PBS} \mathrm{pH} 7.0$. Scan rate: $20 \mathrm{mV} \mathrm{s}^{-1}$

evaluated at different $\mathrm{pH}$ values, from 5 to 8 in phosphate buffer (PBS) $0.1 \mathrm{~mol} \mathrm{~L}^{-1}$. The Figure 5 presents an increase of oxidation current with increasing $\mathrm{pH}$. The $\mathrm{pH} 7$ showed a higher oxidation current. Huang et al. describe in their work for determination of ascorbic acid the highest current also at $\mathrm{pH} 7 .{ }^{25}$

There was a decrease in the analytical signal at $\mathrm{pH} 8$, the basic medium can affect the acid sites present in the silica (SiTiPPCo) causing chemical instability. ${ }^{26}$

Thus, the results show that for the proposed sensor the oxidation of AA is favored at $\mathrm{pH} 7$, as shown previously in the literature. ${ }^{14,25}$

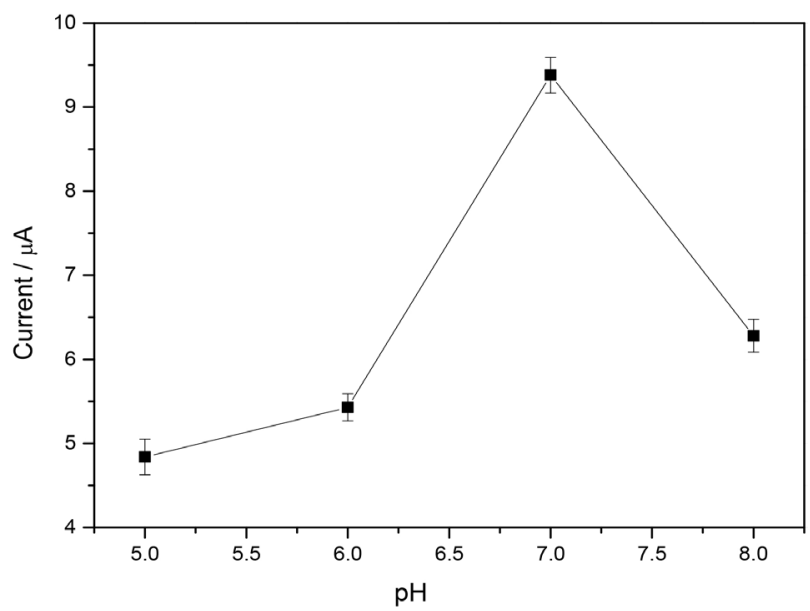

Figure 5. Influence of the $\mathrm{pH}$ on potential anodic peak at $30 \mu \mathrm{mol} \mathrm{L}$ AA in $0.1 \mathrm{~mol} \mathrm{~L}^{-1}$ PBS Scan rate: $20 \mathrm{mV} \mathrm{s}^{-1}$

\subsection{Influence of buffer solution type}

The influence of different buffer solutions on the electrochemical response of the electrode was studied. The buffer solutions evaluated were phosphate, Pipes, Trizma

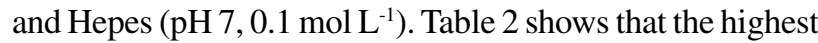
oxidation current was obtained in phosphate buffer. The other buffering systems possibly showed AA affinity, which led to a lower response of the analytical system.
Table 2. Influence of different buffer solutions on the anodic peak current at $30 \mathrm{~mol} \mathrm{~L}^{-1} \mathrm{AA}$ in $0.1 \mathrm{~mol} \mathrm{~L}^{-1} \mathrm{pH}$ 7.0. Scan rate: $20 \mathrm{mV} \mathrm{s}^{-1},(\mathrm{n}=3)^{[\mathrm{a}]}$

\begin{tabular}{cc}
\hline Buffer solution & $\mathbf{I}_{\mathrm{ap}} / \boldsymbol{\mu} \mathbf{A} \pm \mathbf{R S D}$ \\
\hline PBS & $8.56 \pm 0.23$ \\
Pipes & $4.52 \pm 0.17$ \\
Trizma & $3.15 \pm 0.19$ \\
Hepes & $1.12 \pm 0.28$ \\
\hline
\end{tabular}

[a] $n=$ number of determinations

\subsection{Influence of ionic strength}

Figure 6 shows the effect of different concentrations of PBS. The concentration of $0.1 \mathrm{~mol} \mathrm{~L}^{-1}$ presented the highest current in the oxidation of AA. At higher concentrations there was a decrease in analytical signal possibly because the excess of ions made it difficult for the analyte to access the electrode surface.

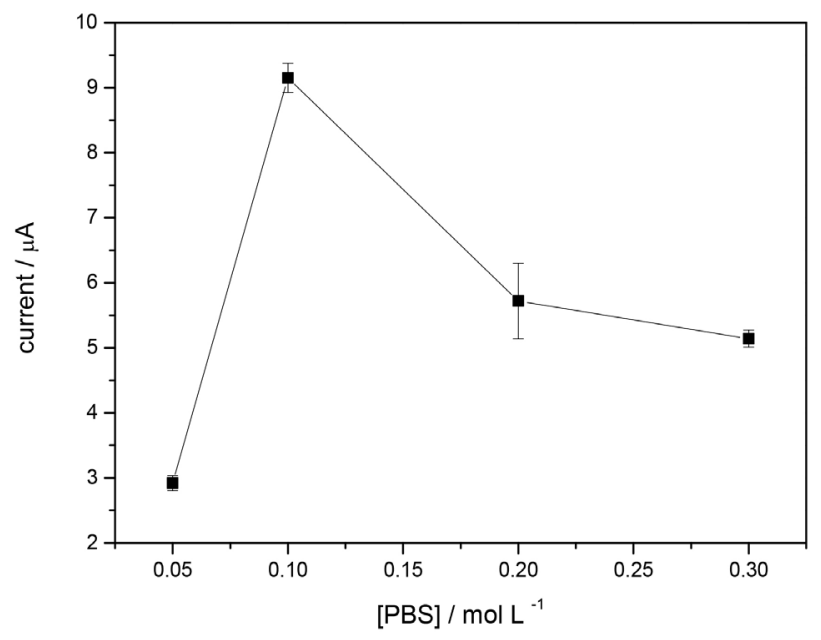

Figure 6. Influence of ionic strength of PBS pH 7.0 on anodic peak current at $30 \mu \mathrm{mol} \mathrm{L}-1$ AA. Scan rate: $20 \mathrm{mV} \mathrm{s}^{-1}$

\subsection{Influence of electrochemical technique on the} proposed sensor

Optimization of the electroanalytical technique is essential to obtain lower values of detection limit, quantification limit and higher sensitivity. Square Wave Voltammetry (SWV) (Amplitude $50 \mathrm{mV}$, Frequency $30 \mathrm{~Hz}$ ) and Differential Pulse Voltammetry (DPV) (Amplitude $60 \mathrm{mV}$, Scan rate $20 \mathrm{mV} \mathrm{s}^{-1}$ ) were evaluated. As can be seen in Table 3, SWV presented higher sensitivity in determination of AA, so it was used in subsequent studies.

\subsection{Method Validation}

After the optimization of the experimental and operational parameters, it was possible to construct the analytical curve for AA as shown in Figure 7.

The Table 4 presents the analytical parameters were 
Table 3. Influence of techniques on sensor response for AA determination Conditions (0.1 mol L-1 PBS pH 7.0), $(\mathrm{n}=3)$

\begin{tabular}{lc}
\hline Electrochemical technique & Sensibility / $\boldsymbol{\mu A ~} \mathbf{~ ~ m o l}^{\mathbf{1}}$ \\
\hline Square Wave Voltammetry (SWV) & 0.20 \\
Differential Pulse Voltammetry (DPV) & 0.09 \\
\hline
\end{tabular}

evaluated: linearity, LOD, LOQ, precision and accuracy. The relative standard deviation (\%) and relative error (\%) were lower than $5 \%$ as recommended. ${ }^{2}$

The intra-day and inter-day precision and accuracy values for AA determination using the proposed sensor were evaluated by three concentrations (low, medium and high), corresponding to $15.00 \mu \mathrm{moL}^{-1}, 30.00 \mu \mathrm{moL}^{-1}$ and $45.00 \mu \mathrm{moL}^{-1}$, respectively. The values obtained are shown in Table 5. The RSD value was below the recommended maximum limit of $5 \%$.

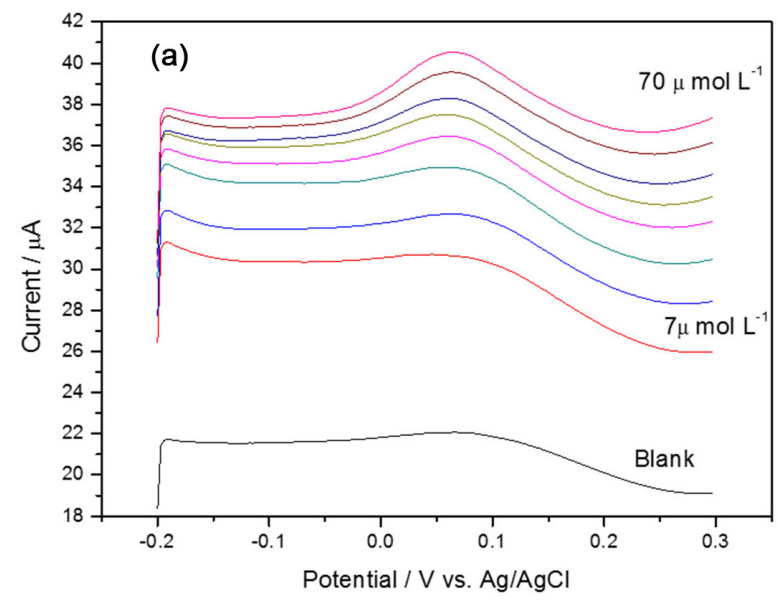

Table 4. Parameters evaluated for the validation of the analytical method $(\mathrm{n}=3)$

\begin{tabular}{lc}
\hline Parameters & \\
\hline Linear Equation & $\mathrm{I}_{\mathrm{ap}}(\mu \mathrm{A})=0,20[\mathrm{AA}]+6.5 \times 10^{-6}$ \\
Coefficient correlation & 0.9986 \\
Linear range $\left(\mu \mathrm{moL}^{-1}\right)$ & $7.0-70.00$ \\
$\mathrm{LOD}\left(\mu \mathrm{moL}^{-1}\right)$ & 1.9 \\
$\mathrm{LOQ}\left(\mu \mathrm{moL}^{-1}\right)$ & 6.4 \\
\hline
\end{tabular}

\subsection{Selectivity of the method}

The selectivity of the developed sensor was evaluated in the presence of excipients contained in the analyzed pharmaceutical sample. The results are presented in Table 6, where it can be seen that the excipients do not interfere in the determination of AA.

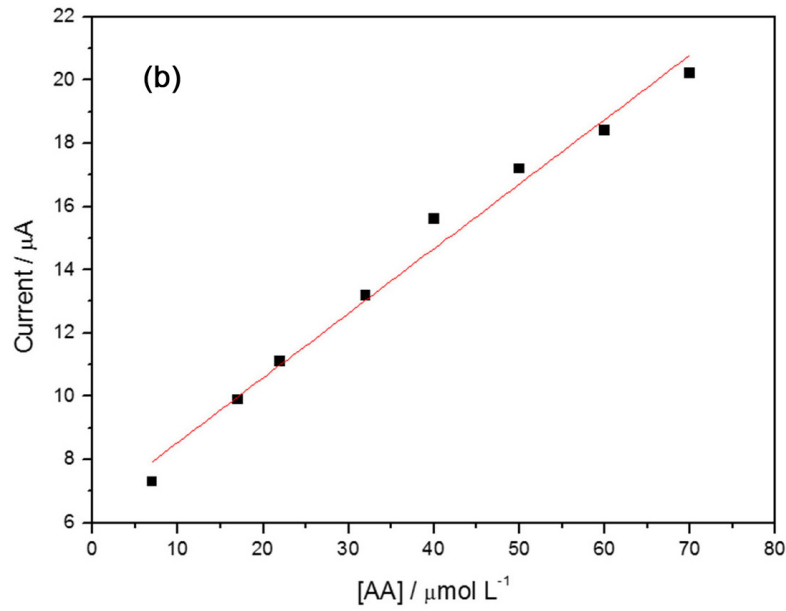

Figure 7. (a) Voltammogram for the determination of AA concentrations obtained for 7 to $70 \mu \mathrm{mol} \mathrm{L}^{-1}$. (b) Analytical curve constructed from voltammogram (Figure 7(a)). Conditions: PBS $0.10 \mathrm{~mol} \mathrm{~L}^{-1}, \mathrm{pH} 7.0$

Table 5. Evaluation of the precision and accuracy of the analytical method

\begin{tabular}{|c|c|c|c|c|}
\hline \multirow{2}{*}{$\frac{\text { Parameters }}{\text { Nominal concentration }}$} & \multirow[t]{2}{*}{ Day } & \multicolumn{3}{|c|}{ Concentrations $\left(\mu \mathrm{mol} \mathrm{L} \mathrm{L}^{-1}\right)$} \\
\hline & & 15.00 & 30.00 & 45.00 \\
\hline \multicolumn{5}{|l|}{ Within day $\left(\mathrm{n}^{[\mathrm{a}]}=3\right)$} \\
\hline \multirow[t]{2}{*}{ Analyzed concentration } & 1 & 15.40 & 30.45 & 45.55 \\
\hline & 2 & 15.33 & 30.48 & 45.74 \\
\hline \multirow[t]{2}{*}{ Precision $(\mathrm{RSD}, \%)^{[\mathrm{b}]}$} & 1 & 0.21 & 0.27 & 0.38 \\
\hline & 2 & 0.19 & 0.24 & 0.35 \\
\hline \multirow[t]{2}{*}{ Accuracy $(\mathrm{RE}, \%)^{[\mathrm{c}]}$} & 1 & 2.47 & 1.53 & 1.42 \\
\hline & 2 & 1.17 & 1.48 & 1.26 \\
\hline \multicolumn{5}{|l|}{ Between day $\left(\mathrm{n}^{[\mathrm{d}]}=2\right)$} \\
\hline Analyzed concentration & & 15.67 & 30.82 & 45.94 \\
\hline Precision $(\mathrm{RSD}, \%)^{[\mathrm{b}]}$ & & 0.59 & 0.47 & 0.63 \\
\hline Accuracy $(\mathrm{RE}, \%)^{[\mathrm{c}]}$ & & 1.55 & 1.48 & 1.39 \\
\hline
\end{tabular}

[a] n=Number of determinations; [b] RSD (\%), precision expressed as relative standard deviation percentage; [c] RE (\%), accuracy expressed as relative error percentage; [d] n=Number of days. 
Table 6. Study of the selectivity of the proposed sensor with the pharmaceutical sample excipients

\begin{tabular}{|c|c|c|c|}
\hline Excipients & $\begin{array}{c}\text { [AA] added } \\
\left(\mu \mathrm{mol} \mathrm{L} \mathbf{L}^{-1}\right)\end{array}$ & $\begin{array}{c}{[\mathbf{A A}] \text { found }} \\
\left(\boldsymbol{\mu m o l} \mathbf{L}^{-1} \pm \mathrm{RSD}\right)\end{array}$ & Recovery (\%) \\
\hline Sorbitol & 30.00 & $29.42( \pm 0.31)$ & 98.07 \\
\hline Aspartame & 30.00 & $30.27( \pm 0.44)$ & 100.90 \\
\hline Citric acid & 30.00 & $30.58( \pm 0.45)$ & 101.93 \\
\hline
\end{tabular}

Table 7. Comparison of the proposed sensor performance with other sensors from the literature

\begin{tabular}{|c|c|c|c|c|}
\hline Electrode & Technique & Linear range $\left(\mu \mathrm{mol} \mathrm{L} \mathrm{L}^{-1}\right)$ & LOD $\left(\mu \mathrm{mol} \mathrm{L} \mathbf{L}^{-1}\right)$ & Ref. \\
\hline PPy hydrogel/GCE ${ }^{[a]}$ & SWV & $2.5-1500$ & 1.28 & [13] \\
\hline $\mathrm{G}-30^{[\mathrm{b}]}$ & SWV & $5.0-1000$ & 17.80 & [14] \\
\hline $\begin{array}{l}\text { poly-Trypan modified } \\
\text { GCE }^{[c]}\end{array}$ & DPV & $1.0-630$ & 0.10 & {$[16]$} \\
\hline $\mathrm{sG} / \mathrm{Pd} / \mathrm{GCE}^{[\mathrm{d}]}$ & DPV & $300-1300$ & 22.00 & {$[27]$} \\
\hline SMT/MWCNTs/PGE ${ }^{[e]}$ & DPV & $0.319-60$ & 0.096 & [28] \\
\hline GPtNPs-GCE ${ }^{[\mathrm{f}]}$ & $\mathrm{CV}^{[\mathrm{g}]}$ & $20.889-300$ & 300 & [29] \\
\hline CPE-SiTiPPCo & SWV & $7-70$ & 1.9 & This work \\
\hline
\end{tabular}

[a] modified glassy carbon electrode with polypyrrole hydrogel; [b] graphene ink coated glass; [c] modified glassy carbon electrode with poly-Trypan Blue; [d] modified glassy carbon electrode with reduced graphene oxide and palladium; [e] graphite electrode coated on sodium nanosmectite (SMT) mineral and MWCNTs (multi-walled carbon nanotubes); [f] modified glassy carbon electrode with platinum nanoparticles decorated graphene (GPtNPs) nanocomposite; [g] cyclic voltammetry.

CPE-SiTiPPCo sensor performance was compared with other sensors reported in the literature. According to Table 7, the proposed sensor presents a satisfactory performance, with a low detection limit associated with a simple preparation method and with the advantage of electrode surface renewal, which extends the use of the sensor.

\subsection{Determination of AA in real sample}

In the determination of AA, which acts as an active principle in various pharmaceutical formulations, were used Energil $\mathrm{C}^{\circledR}$ tablets. Samples containing known AA concentrations were analyzed and the results found showed high recovery percentages (Table 8), showing that the EPC-SiTiPPCo was effective in determining AA for this type of sample.

Table 8. Determination of AA in pharmaceutical formulation samples $(n=3)$

\begin{tabular}{|c|c|c|}
\hline $\begin{array}{c}\text { [AA] added } \\
\left(\mu \mathrm{mol} \mathrm{L} \mathbf{L}^{-1}\right)\end{array}$ & $\begin{array}{c}\text { [AA] found } \\
\left(\mu \mathrm{mol} \mathrm{L} \mathbf{L}^{-1} \pm \mathrm{RSD}\right)\end{array}$ & Recovery (\%) \\
\hline 15.00 & $15.88( \pm 0.55)$ & 105.87 \\
\hline 45.00 & $47.11( \pm 1.12)$ & 104.69 \\
\hline
\end{tabular}

\section{Conclusions}

The proposed electrode presented excellent performance in the AA determination. The optimization of experimental and operational parameters contributed to the increase of the sensitivity.
The sensor also presented attractive features such as easy preparation, the possibility of renewal of the electrode surface and relatively low cost. The use of the sensor in the AA analysis in samples of pharmaceutical formulation without interference from other species and with high recovery rates attested to the effectiveness of the proposed method.

\section{Acknowledgements}

The authors are grateful to Fundação de Amparo à Pesquisa do Estado de Minas Gerais (FAPEMIG), Conselho Nacional de Desenvolvimento Científico e Tecnológico (CNPq) and Coordenação de Aperfeiçoamento de Pessoal de Nível Superior (CAPES) for financial support. This work is a collaboration research project of members of the Rede Mineira de Química (RQ-MG) supported by FAPEMIG. The authors are grateful also the professor Emerson Schwingel Ribeiro of Universidade Federal do Rio de Janeiro for donating the material SiTi-PP.

\section{References}

1. Pisoschi, A. M.; Pop, A.; Serban, A. I.; Fafaneata, C.; Electrochemical methods for ascorbic acid determination. Electrochimica Acta 2014, 121, 443. [CrossRef]

2. Zhang, W.; Liu, L.; Li, Y.; Wang, D.; Ma, H.; Shi, Y.; Ren, Han, Y.; Ye, B.-C.; Electrochemical Sensing Platform Based on 
the Biomass-Derived Microporous Carbons for Simultaneous Determination of Ascorbic acid, Dopamine, and Uric acid. Biosensors and Bioelectronics 2018, 121, 96. [CrossRef]

3. Murali, A.; Lan, Y. P.; Sarswat, P. K.; Free, M. L.; Synthesis of $\mathrm{CeO} 2 /$ reduced graphene oxide nanocomposite for electrochemical determination of ascorbic acid and dopamine and for photocatalytic applications. Materials Today Chemistry 2019, 12, 222.[CrossRef]

4. Rostami, S.; Mehdinia, A.; Jabbari, A.; Seed-mediated grown silver nanoparticles as a colorimetric sensor for detection of ascorbic acid. Spectrochimica Acta Part A: Molecular and Biomolecular Spectroscopy 2017, 180, 204. [CrossRef]

5. Xu, S.; Dong, X.; Chen, S.; Zhao, Y.; Shan, G.; Sun, Y.; Chen, Y.; Liu, Y.; The preparation of high-index facet $\mathrm{Au} / \mathrm{Cu} \mathrm{NRs}$ and their application for colorimetric Determination ascorbic acid. Sensors and Actuators B: Chemical 2019, 281, 375. [CrossRef]

6. Olgun, F. A. O.; Ozyurt, D.; Berker, K. I.; Demirata, B.; Apak, R.; Folin-Ciocalteu spectrophotometric assay of ascorbic acid in pharmaceutical tablets and orange juice with $\mathrm{pH}$ adjustment and pre-extraction of lanthanum(III)-flavonoid complexes. Journal of the Science of Food and Agriculture 2014, 94, 2401. [CrossRef]

7. Bazel, Y.; Riabukhina, T.; Tirpák, J.; Spectrophotometric determination of ascorbic acid in foods with the use of vortexassisted liquid-liquid microextraction. Microchemical Journal 2018, 143, 160. [CrossRef]

8. Gioia, M. G.; Andreatta, P.; Boschetti, S.; Gatti, R.; Development and validation of a liquid chromatographic method for the determination of ascorbic acid, dehydroascorbic acid and acetaminophen in pharmaceuticals. Journal of Pharmaceutical and Biomedical Analysis 2008, 48, 331. [CrossRef]

9. Wang, G.; Chen, Z.; Chen, L.; Mesoporous silica-coated gold nanorods: towards sensitive colorimetric sensing of ascorbic acid via target-induced silver overcoating. Nanoscale 2011, 3, 1756. [CrossRef]

10. Costa, B. M. C.; Prado, A. A.; Oliveira, T. C.; Bressan, L. P.; Munoz, R. A. A.; Batista, A. D., Silva, J. A. F.; Richter, E. M.; Fast methods for simultaneous determination of arginine, ascorbic acid and aspartic acid by capillary electrophoresis. Talanta 2019, 204, 353. [CrossRef]

11. Gong, J.; Lu, X.; An, X.; Carbon dots as fluorescent off-on nanosensors for ascorbic acid detection. RSC Advances 2015, 5, 8533. [CrossRef]

12. Zhu, Q.; Bao, J.; Huo, D.; Yang, M.; Wu, H.; Hou, C.; Zhão, Y.; Luo. X.; Fa, H.; 3DGH-Fc based electrochemical sensor for the simultaneous determination of ascorbic acid, dopamine and uric acid. Journal of Electroanalytical Chemistry 2017, 799, 459. [CrossRef]

13. Wang, M.; Cui, M.; Liu, W.; Liu, X.; Highly dispersed conductive polypyrrole hydrogels as sensitive sensor for simultaneous determination of ascorbic acid, dopamine and uric acid. Journal of Electroanalytical Chemistry 2019, 832, 174. [CrossRef]

14. Fu, L.; Wang, A.; Lai, G.; Su, W.; Malherbe, F.; Yu, J.; Lin, G-T.; Yu, A.; Defects regulating of graphene ink for electrochemical determination of ascorbic acid, dopamine and uric acid. Talanta 2018, 180, 248. [CrossRef]
15. Shao, L.; Wang, X.; Yang, B.; Wang, Q.; Tian, Q., Ji, Z.; Zhang, J.; A Highly Sensitive Ascorbic Acid Sensor Based on Hierarchical Polyaniline Coated Halloysite Nanotubes Prepared by Electrophoretic Deposition. Electrochimica Acta 2017, 255, 286. [CrossRef]

16. Taei, M.; Jamshidi, M. S.; A voltammetric sensor for simultaneous determination of ascorbic acid, noradrenaline, acetaminophen and tryptophan. Microchemical Journal 2017, 130, 108. [CrossRef]

17. Ribeiro, E. S.; Dias, S. L. P.; Gushikem, Y.; Kubota, L. T.; Cobalt(II) porphyrin complex immobilized on the binary oxide $\mathrm{SiO} / \mathrm{Sb} 2 \mathrm{O} 3$ : electrochemical properties and dissolved oxygen reduction study. Electrochimica Acta 2004, 49, 829. [CrossRef]

18. Cao, M.; Yin, X.; Bo, X.; Guo, L.; High-performance electrocatalyst based on metal-organic framework/macroporous carbon composite for efficient detection of luteolin. Journal of Electroanalytical Chemistry 2018, 824, 153. [CrossRef]

19. Wang, Y.; Sauriat-Dorizon, H.; Korri-Youssoufi, H.; Direct electrochemical DNA biosensor based on reduced graphene oxide and metalloporphyrin nanocomposite. Sensors and Actuators B: Chemical 2017, 251, 40.[CrossRef]

20. Mendonça Costa, L.; Ribeiro, E. S.; Segatelli, M. G.; do Nascimento, D. R.; de Oliveira, F. M.; Tarley, C. R. T.; Adsorption studies of $\mathrm{Cd}(\mathrm{II})$ onto $\mathrm{A} 12 \mathrm{O} 3 / \mathrm{Nb} 2 \mathrm{O} 5$ mixed oxide dispersed on silica matrix and its on-line preconcentration and determination by flame atomic absorption spectrometry. Spectrochimica Acta Part B: Atomic Spectroscopy 2011, 66, 329. [CrossRef]

21. Agência Nacional de Vigilância Sanitária. Resolução re n ${ }^{\circ} 899$ de 29 de maio de 2003 - determina a publicação do guia para validação de métodos analíticos e bioanalíticos. Diário Oficial da União, 2003. [Link]

22. Machado, J. K. F. B.; Marçal, A. L.; de Lima, O. J.; Ciuffi, K. J.; Nassar, E. J.; Calefi, P. S.; Materiais híbridos orgânicoinorgânicos (ormosil) obtidos por sol-gel com potencial uso como filtro solar. Química Nova 2011, 34, 945. [CrossRef]

23. Giarola, J. de F.; Borges, K. B.; Tarley, C. R. T.; de Oliveira, F. M.; Ribeiro, E. S.; Pereira, A. C.; Development and application of graphite-SiO2 /A12O3/Nb2O5 -methylene blue (GRP$\mathrm{SiAlNb-MB)} \mathrm{composite} \mathrm{for} \mathrm{electrochemical} \mathrm{determination}$ of dopamine. Arabian Journal of Chemistry 2017, 10, 430. [CrossRef]

24. Dinatale, C.; Paolesse, R.; Damico, A.; Metalloporphyrins based artificial olfactory receptors. Sensors and Actuators B: Chemical 2007, 121, 238. [CrossRef]

25. Huang, D.; Li, X.; Chen, M.; Chen, F.; Wan, Z.; Rui, R.; Wang, R.; Fan, S.; Wu, H.; An electrochemical sensor based on a porphyrin dye-functionalized multi-walled carbon nanotubes hybrid for the sensitive determination of ascorbic acid. Journal of Electroanalytical Chemistry 2019, 841, 101. [CrossRef]

26. Marco, J. P.; Borges, K. B.; Tarley, C. R. T.; Ribeiro, E. S.; Pereira, A. C.; Development and application of an electrochemical biosensor based on carbon paste and silica modified with niobium oxide, alumina and DNA ( $\mathrm{SiO} 2 / \mathrm{Al} 2 \mathrm{O} 3 / \mathrm{Nb} 2 \mathrm{O} 5 / \mathrm{DNA})$ for amitriptyline determination. Journal of Electroanalytical Chemistry 2013, 704, 159. [CrossRef] 
27. Renjini, S.; Abraham, P.; Aparna, S.; Kumary, V. A.; GraphenePalladium Composite for the Simultaneous Electrochemical Determination of Epinephrine, Ascorbic acid and Uric Acid. Journal of The Electrochemical Society 2019, 166, B1321. [CrossRef]

28. Bayraktepe, D. E.; Yazan, Z.; Önal, M.; Sensitive and cost effective disposable composite electrode based on graphite, nanosmectite and multiwall carbon nanotubes for the simultaneous trace level detection of ascorbic acid and acetylsalicylic acid in pharmaceuticals. Talanta 2019, 203, 131. [CrossRef]

29. Kumar, M. A.; Lakshminarayanan, V.; Ramamurthy, S. S.; Platinum nanoparticles-decorated graphene-modified glassy carbon electrode toward the electrochemical determination of ascorbic acid, dopamine, and paracetamol. Comptes Rendus Chimie 2019, 22, 58. [ CrossRef] 